\title{
Accountability Through Self-Governance in EU Economic Governance
}

\author{
ANA BOBIĆ $*$
}

\section{Introduction}

The introduction of the Economic and Monetary Union (EMU) in the Maastricht Treaty, ${ }^{1}$ a step of yet unprecedented integration, was followed by a sharp decline in public support present in previous Treaty revisions. ${ }^{2}$ The development was followed by the vast literature on the democratic deficit of the EU, most prominently advocated by Fritz Scharpf. ${ }^{3}$ In addition, the literature argued that European integration expanded into areas traditionally considered core state powers, ${ }^{4}$ resulting in a retreat to new intergovernmental modes of governance, ${ }^{5}$ such as differentiation through opt-outs and the establishment of regulatory agencies. ${ }^{6}$

These concerns were particularly exacerbated during the euro crisis, which has been much maligned in terms of its lack of democratic accountability. ${ }^{7}$ The EU's

${ }^{\star}$ I am grateful to Adina Maricut-Akbik, Josephine van Zeben, Petra Weingerl and Mark Dawson for their useful feedback and comments.

${ }^{1}$ Treaty Establishing the European Community (TEC) [1992] OJ C 224/1.

${ }^{2} \mathrm{JHH}$ Weiler, The Constitution of Europe. 'Do the New Clothes have an Emperor?' and Other Essays on European Integration (Cambridge, Cambridge University Press, 1999) 4; N MacCormick, Questioning Sovereignty (Oxford University Press, 1999) 98-99.

${ }^{3}$ F Scharpf, Governing in Europe: Effective and Democratic? (Oxford, Oxford University Press, 1999). For an overview of the argument and the relevant supporting literature, see A Moravscik, 'In Defense of the "Democratic Deficit": Reassessing Legitimacy in the European Union' (2002) 40 Journal of Common Market Studies 603; VA Schmidt, 'Democracy and Legitimacy in the European Union Revisited: Input, Output and “Throughput”" (2013) 61 Political Studies 2.

${ }^{4} \mathrm{P}$ Genschel and M Jachtenfuchs, 'More Integration, Less Federation: The European Integration of Core State Powers' (2016) 23 Journal of European Public Policy 42.

${ }^{5} \mathrm{CJ}$ Bickerton et al, 'The New Intergovernmentalism: European Integration in the Post-Maastricht Era' (2015) 53 Journal of Common Market Studies 703.

${ }^{6}$ Genschel and Jachtenfuchs, above n 4, 46-48. For an overview of the literature, see A MaricutAkbik, 'EU Politicization beyond the Euro Crisis: Immigration Crises and the Politicization of Free Movement of People' (2018) 1 Comparative European Politics 1, 3-4.

${ }^{7} \mathrm{C}$ Fasone, 'European Economic Governance and Parliamentary Representation: What Place for the European Parliament?' (2014) 20 European Law Journal 164; M Dawson, 'The Legal and Political Accountability Structure of "Post-crisis" EU Economic Governance' (2015) 53 Journal of Common 
strong reliance on output legitimacy strengthens this claim: the emphasis on authority derived from regulatory effectiveness and market integration prosperity ${ }^{8}$ over process-centred democratic controls has been particularly visible in the ad hoc creation of the EU's economic governance mechanisms. ${ }^{9}$ This result-oriented approach demonstrated the weaknesses of established accountability systems, such as judicial review and parliamentary scrutiny at both the national and EU level.

In this contribution I argue that the current institutional set-up of EU economic governance, specifically post-crisis, suffers from two main malaises which as its result has political inequality between EU citizens. First, it is designed so as to favour the principle of equality of Member States to the detriment of the principle of solidarity between Member States, which creates asymmetries in influence on the political realm and access to accountability mechanisms among EU citizens. Second, it relies on nation-state inspired models of democratic legitimation which are not appropriate for its specific transnational context, which is increasingly regulated through ad hoc and non-typical instruments. Majoritarian representation is, as will be shown, unable to ensure legitimation and accountability equally for citizens of all Member States. Ultimately, the current architecture of EU economic governance limits the number of those able to contest political decisions, the number of routes available for such contestation, and the ultimate answerability of decision-makers. Rather, accountability needs to be separated from democratic representation rooted in the tradition of nation states, ${ }^{10}$ and to focus on achieving political equality of citizens as the crucial tenet of democracy.

While the present work does not offer a detailed proposal for institutional reform, it provides a starting point for further research, outlining its main theoretical features. In what follows, I argue that legal accountability in economic governance is currently suffering from two main deficiencies: first, the individual has been taken out of the equation in the design of economic governance mechanisms; and, second, the imitated nation-state accountability mechanisms have proved inadequate in ensuring the individual's ability to hold decision-makers in economic governance to account. Subsequently, I set out a proposal for accountability through self-governance and its normative underpinnings. The final part offers a broad-brush attempt at applying the model to economic governance mechanisms, and concludes with some open questions for further research.

\footnotetext{
Market Studies 976, 983; J Pisani-Ferry, 'Rebalancing the Governance of the Euro Area' in M Dawson, $\mathrm{H}$ Enderlein and C Joerges (eds), Beyond the Crisis. The Governance of Europe's Economic, Political, and Legal Transformation (Oxford, Oxford University Press, 2015) 72; A Maatsch, Parliaments and the Economic Governance of the European Union: Talking Shops or Deliberative Bodies? (London, Routledge, 2016).

${ }^{8}$ T Isiksel, Europe's Functional Constitution (Oxford, Oxford University Press, 2016) 6, 13.

${ }^{9}$ ibid 224 onwards. See also, J Habermas, 'Democracy, Solidarity and the European Crisis' in A-M Grozelier et al (eds), Roadmap to a Social Europe (Social Europe Report, 2013) available at: www. ictu.ie/download/pdf/roadmap_to_social_europe_sej_oct_2013.pdf\#page=9, 4 .

${ }^{10} \mathrm{~J}$ Teubner, 'Quod omnes tangit: Transnational Constitutions Without Democracy?' (2018) (S1) Journal of Law and Society S5, S22.
} 


\section{Problems of Accountability in Existing Economic Governance Mechanisms}

\section{Deficiencies Stemming from the Design of the EU's Economic Governance Mechanisms}

On an abstract level, the principle of solidarity between Member States ${ }^{11}$ may be said to be at the heart of post-crisis instruments of economic governance. ${ }^{12}$ Its more practical expression has, however, arguably been guided by the principle of equality of Member States as articulated in Article 4(2) TEU. The principle of equality has seen its expression, for example, in the prohibition of monetary financing envisaged in Article 123 TFEU, as well as in the no bail-out clause contained in Article 125 TFEU, ${ }^{13}$ which presumes equality between Member States to an extent that each of them is liable for their own failures. ${ }^{14}$ In that sense, it overlooks the economic spillovers in the area of not only a shared market, but also a shared currency, and the ensuing need for risk-sharing among Member States. Admittedly, Article 122 TFEU addresses situations in which Member States may, acting through the Council, provide help in times of severe difficulties for individual Member States, relying on the principle of solidarity between Member States. However, Article 122 TFEU inherently carries the presumption that while help may be granted, the cause and primary responsibility for resolving the difficulty lies with the Member State concerned. Otherwise, the Member State receiving the aid may be inclined not to implement a sound budgetary policy, and ultimately free ride on the assistance granted. ${ }^{15}$

Moreover, the European Stability Mechanism (ESM) has been established by way of an international treaty, with a set-up designed so as to ensure that the voting rights in the ESM reflect the respective contributions of Member States. ${ }^{16}$ Using economic criteria in order to determine political rights is problematic: inequalities between creditor and debtor Member States are necessarily prolonged, as the latter are inevitably in the position of accepting the conditions attached to financial assistance measures, ${ }^{17}$ as the case of Greek bail-outs during the Syriza's

\footnotetext{
${ }^{11}$ Found in Art 3(3) TEU.

${ }^{12}$ E Küçük, 'Solidarity in EU Law. An Elusive Political Statement or a Legal Principle with Substance?' (2016) 23 Maastricht Journal of European and Comparative Law 965, 981.

${ }^{13}$ A McDonnell, 'Solidarity, Flexibility and the Euro-crisis. Where Do Principles Fit In?' in LS Rossi and F Casolari (eds), The EU after Lisbon Amending or Coping with the Existing Treaties? (Heidelberg, Springer, 2014) 78 .

${ }^{14}$ Opinion of AG Kokott in Case C-370/12 Pringle EU:C:2012:675, 128-30; Case C-62/14 Gauweiler EU:C:2015:400, 100.

${ }^{15}$ In that sense, see Case C-370/12 Pringle EU:C:2012:756136, 100.

${ }^{16}$ Art 4(7) of the ESM Treaty.

${ }^{17} \mathrm{~F}$ Fabbrini, Economic Governance in Europe: Comparative Paradoxes and Constitutional Challenges (Oxford, Oxford University Press, 2016) 15.
} 
first year in government shows. ${ }^{18}$ Taking into account that voting rights in the ESM do not represent all citizens of the EU equally, the composition of the ESM results in political inequality between citizens depending on the economic strength of their Member State. This leads to domination of creditor states, and their superiority over citizens of debtor states, undermining their political autonomy ${ }^{19}$ in devising, applying and contesting the conditions stemming from bail-out arrangements sourced in the ESM.

The preliminary reference submitted by German Bundesverfassungsgericht in Gauweiler sought confirmation from the Court of Justice that the Outright Monetary Transactions (OMT) Programme, announced by the European Central Bank (ECB) in the wake of the euro crisis by way of a press release, will not undermine the conditionality of financial assistance mechanisms such as the EFSF and the ESM. ${ }^{20}$ Unless strict conditionality is followed, the argument of the Bundesverfassungsgericht goes, budgetary autonomy of Member States would be virtually inexistent, as financial assistance could be granted without the Bundestag's approval. Rather, the reasoning proceeds, conditionality is an expression of equality of sovereign Member States who are 'Masters of the Treaties'. In addition, the Bundesverfassungsgericht sought to determine whether the OMT mechanism goes against the prohibition of monetary financing set out in Article 123 TFEU and the no bail-out clause in Article 125 TFEU. The Court of Justice provided a reasoning defending the OMT mechanism as containing in-built safeguards that would not go against these Treaty prohibitions, ${ }^{21}$ therefore not undermining the equality of Member States. It confined its analysis to ensuring the principles of conferral and proportionality are respected. As in the assessment of the ESM, the Court of Justice made no reference to the principle of solidarity between Member States.

The current Italian political and financial crisis demonstrates a rhetoric of EU leaders remarkably resembling the one used in the height of the Greek bail-out negotiations and aggravates the problems connected to the insistence on formal equality of Member States. ${ }^{22}$ Examples of this include Juncker calling upon Italians to 'work harder and be less corrupt'; ${ }^{23}$ the German MEP Ferber announcing it

\footnotetext{
${ }^{18}$ BBC News, 'Greece’s Varoufakis: "No debt talks with EU-IMF troika”' (30 January 2015), available at: www.bbc.com/news/world-europe-31055069.

${ }^{19}$ EO Eriksen, 'Structural Injustice: the Eurozone Crisis and the Duty of Solidarity' ARENA Working Paper 4/2017, 13.

${ }^{20}$ German Bundesverfassungsgericht Case 2 BvR 2728/13 Gauweiler, Order of 14 January 2014, available at: www.bundesverfassungsgericht.de/SharedDocs/Entscheidungen/EN/2014/01/ rs201401142bvr272813en.html, 100.

${ }^{21}$ Case C-62/14 Gauweiler, above n 14, 103-07.

${ }^{22}$ For an analysis of developments from 2010 to 2012 which underline the same approach of creditor toward debtor states, see CR Henning, 'The ECB as a Strategic Actor. Central Banking in a Politically Fragmented Monetary Union' in JA Caporaso and M Rhodes (eds), The Political and Economic Dynamics of the Eurozone Crisis (Oxford, Oxford University Press, 2016) 189.

${ }^{23}$ The Guardian, 'Juncker: Italians need to work harder and be less corrupt' 31 May 2018, available at: www.theguardian.com/world/2018/may/31/italy-cancelled-league-rallies-signal-political-impassemay-soon-end?CMP=share_btn_tw.
} 
might be necessary for the Troika to 'march into Rome'; ${ }^{24}$ and German Chancellor Merkel calling for more governmental oversight over the reformed ESM, that is to be heavily rooted in conditionality. ${ }^{25}$ Regrettably all these views presuppose a separation of peoples of Europe, who can only be joined politically through their Member State representatives at the EU level, or through their nationally elected representatives in the European Parliament. Equally, the euro crisis is regarded neither as one with a joint origin, nor as one with a joint comprehensive solution. ${ }^{26}$ Each (equal) Member State for itself, regardless of the consequences this has for its citizens.

\section{The Inadequacy of Nation-State Imitated Legitimation and Accountability Mechanisms}

A further specificity of EU economic governance is its reliance on ad hoc and non-typical instruments that are unable to ensure political equality of EU citizens by way of majoritarian representation on the national level, and judicial review on both the national and EU level. The examples of the ESM and the OMT will again serve to portray these deficiencies.

Establishing the ESM through an international law treaty includes solely national governments in the process of its creation and design, whereas the doctrines of primacy and direct effect do not apply. The role of the citizen is reduced to national elections, leaving them without any influence as regards creating, designing and ultimately implementing the obligations stemming from the ESM. As the already mentioned Greek bail-out case aptly showed, the Greek voter ultimately had no influence on the implementation of austerity measures imposed by the Troika, regardless of the anti-Troika campaign that led Syriza to win national elections. ${ }^{27}$ Because the ESM does not have an established accountability structure, nor is it accountable within the system of EU law, the Greek citizen lost all ability to influence or change the austerity requirements imposed by the Troika. The German citizen, on the other hand, is represented in the ESM with a decisive influence in its voting structure, and her government is the one creating conditions for financial assistance. Pernice argues that the insistence of Member States on remaining the masters of the Treaties, ${ }^{28}$ meaning public international law applies as is also the case with the ESM, rely on national procedures as the only possible source of EU's legitimation, ultimately enabling the bypassing of citizens in decision-making. ${ }^{29}$

\footnotetext{
${ }^{24}$ Twitter, available at: twitter.com/StefanLeifert/status/1001825130912370688.

${ }^{25}$ Reuters, 'Highlights of Merkel interview on Europe' (3 June 2018), available at www.reuters.com/ article/us-europe-merkel-highlights/highlights-of-merkel-interview-on-europe-idUSKCN1IZ0KN.

${ }^{26}$ McDonnell, above n 13, 74-75.

${ }^{27}$ See above, $\mathrm{n} 18$. For an analysis on how the ESM decreased the importance of national parliaments' budgetary autonomy and the limited role of the European Parliament, see Fasone, above $n 7$.

${ }^{28}$ German Bundesverfassungsgericht Case 2 BvR 2728/13 Gauweiler, above n 20, 26.

${ }^{29}$ I Pernice, 'Multilevel Constitutionalism and the Crisis of Democracy in Europe' (2015) 11 European Constitutional Law Review 541, 543. See also, Pisani-Ferry, above n 7, 79.
} 
Academic discourse, ${ }^{30}$ however, focuses predominantly on improvement in parliamentary control of the ESM, mimicking the default legitimation route on the national level. For example, in its report on the ESM, Transparency International found serious problems with the accountability structure of the ESM, and called upon the European Parliament to increase its oversight. ${ }^{31}$ While such reforms would formally increase supervision over the ESM and place more focus on the influence of the citizen rather than of Member States, it would in practice keep the citizen equally, if not further, ${ }^{32}$ removed from any influence on the ESM's functioning. The powers of the European Parliament, although increased over time, have not provided a genuine parliamentary oversight as imagined on the nation-state level. ${ }^{33}$

Judicial review of the ESM at the EU level was weak ${ }^{34}$ to non-existent, ${ }^{35}$ stemming primarily from the fact that the ESM is an international treaty, meaning that the Court of Justice cannot review it in light of the Charter of Fundamental Rights. ${ }^{36}$ Admittedly, the Court of Justice appears to be expanding its approach, by reviewing national measures implementing austerity requirements - however in very limited circumstances. ${ }^{37}$ Equally, the preponderance of national courts did not submit preliminary references to the Court of Justice when reviewing austerity measures imposed through bail-outs - the Court of Justice itself initially rejected them as inadmissible ${ }^{38}$ - resulting in an inability of the current system of

\footnotetext{
${ }^{30}$ See, eg, J Tomkin, 'Contradiction, Circumvention and Conceptual Gymnastics: The Impact of the Adoption of the ESM Treaty on the State of European Democracy' (2013) 14 German Law Journal 169, 185; B Rittberger, 'Integration without Representation? The European Parliament and the Reform of Economic Governance in the EU' (2014) Journal of Common Market Studies 1174; McDonnell, above n 13,76 .

${ }^{31}$ Currently, the Managing Director appears before the European Parliament's Committee on Economic and Monetary Affairs (ECON) whenever invited, and answers questions. Transparency International, 'From crisis to stability. How to make the European Stability Mechanism transparent and accountable' (2017), available at: transparency.eu/wp-content/uploads/2017/03/ESM_Report_ DIGITAL-version.pdf, 36.

${ }^{32}$ The turnout for European Parliament elections was $42.61 \%$, the lowest since the introduction of direct elections for the representatives to the European Parliament in 1979. See: www.europarl.europa. eu/elections2014-results/en/turnout.html. This percentage is consistently lower than the turnout to national parliamentary elections in all Member States save for Estonia. See F Fislage, 'EU Elections Where Are the Voters? Study about the low turnout in new EU Member States' (2015) Facts and Findings No 165 Konrad Adenauer Stiftung, available at: www.kas.de/wf/doc/kas_40621-544-2-30. pdf?150304143237, 4.

${ }^{33}$ Habermas, above n 9, 4 .

${ }^{34}$ See Case C-370/12 Pringle, above n 15.

${ }^{35}$ Where the review of financial assistance measures based on Memoranda of Understanding were rejected as inadmissible. See A Hinarejos, 'The Role of Courts in the Wake of the Eurozone Crisis' in M Dawson, H Enderlein and C Joerges (eds), Beyond the Crisis. The Governance of Europe's Economic, Political, and Legal Transformation (Oxford, Oxford University Press, 2015) 119.

${ }^{36}$ Case C-370/12 Pringle, above n 15, 180.

${ }^{37}$ When deciding whether to cut judges' salaries, an austerity measure introduced to meet the requirements of the bail-out, the Court of Justice did not mention the ESM or any other financial assistance mechanism in the legal context of the judgment, and focused solely on the interpretation of the principle of judicial independence from Art 19(1) TEU, which it concluded was impaired by the measure in question. Case C-64/16 Associação dos Juízes Portugueses EU:C:2018:117.

${ }^{38}$ For an overview of cases, see Hinarejos, above n 35, 126-28.
} 
judicial review to provide equal access to legal accountability to all EU citizens, and the differences are in particular visible between citizens of different debtor states. Finally, not all national courts have the same position in their constitutional set-up to review the ESM and measures stemming from it. For example, the German Bundesverfassungsgericht is seen as the dominant national constitutional court in the EU, being one of the most cited courts EU-wide, and the most prominent one in questioning the decisions of the Court of Justice. ${ }^{39}$ However, it is also seen as pushing the ordoliberal agenda in the EU's economic policy, ${ }^{40}$ therefore depriving citizens of other Member States having any say in the economic rationale behind governance mechanisms. This ultimately means that the ability to hold decision-makers to account depends on the behaviour of national courts, and their position in national legal systems. ${ }^{41}$

The shortcoming of transplanting nation-state rooted mechanisms of legitimation and accountability is further visible in the creation and review of the OMT mechanism. The mechanism was announced in a press release ${ }^{42}$ of an uncertain legal nature, ${ }^{43}$ without any ability of citizens to influence it through their national representatives. The Governing Council that issued the press release is composed of six members of the ECB's Executive Board (which would serve as a representation of national governments' given that they are appointed by the Council) and governors of national central banks of Eurozone countries. Although majoritarian representation is attempted to be ensured through the Council's appointment of the Executive Board, the ad hoc nature of a press release bypassed any influence of the Council and effectively failed in ensuring the representation of EU citizens in the decision-making of the ECB.

In the OMT preliminary reference before the Court of Justice, ${ }^{44}$ the German Bundesverfassungsgericht placed an emphasis on the influence the programme would have on the budgetary autonomy of the Bundestag. It placed majoritarian representation at the centre of analysis, as the right to vote effectuated through budgetary autonomy is considered part of Germany's unamendable constitutional identity. ${ }^{45}$ The Court of Justice, on the other hand, addressed Germany's concerns

\footnotetext{
${ }^{39} \mathrm{G}$ Anagnostaras, 'Activation of the ultra vires Review: The Slovak Pensions Judgment of the Czech Constitutional Court' (2013) 14 German Law Journal 959, 959; RD Kelemen, 'On the Unsustainability of Constitutional Pluralism. European Supremacy and the Survival of the Eurozone' (2016) 23 Maastricht Journal of European and Comparative Law 136; FC Mayer, 'Rashomon in Karlsruhe: A Reflection on Democracy and Identity in the European Union: The German Constitutional Court's Lisbon Decision and the Changing Landscape of European Constitutionalism' (2011) 9 ICON 757.

${ }^{40}$ C Joerges, "'Brother, Can You Paradigm?"” (2014) 12 ICON 772, 780.

${ }^{41}$ See also, Transparency International, above n 31, 36.

42 'Technical Features of Outright Monetary Transactions', Governing Council of the European Central Bank (6 September 2012), available at; www.ecb.europa.eu/press/pr/date/2012/html/pr120906_ 1.en.html.

${ }^{43}$ The Court of Justice found it to be pertinent to the proceedings before the referring court, and thus admissible for interpretation. Case C-62/14 Gauweiler, above n 14) 27-28.

${ }^{44}$ German Bundesverfassungsgericht Case 2 BvR 2728/13 Gauweiler, above n 20.

${ }^{45} \mathrm{ibid}, 28$ and cross-referencing the reasoning from its Maastricht decision (Cases 2 BvR 2134/92 and 2159/92 Brunner, Judgment of 12 October 1993) at 19. Such an approach is an expression of the
} 
through ensuring that the OMT mechanism does not provide assistance contrary to Articles 123 and 125 TFEU, nor that it undermines the conditionality of the ESM. However, as regards the finding that the mechanism falls within the scope of ECB's competence, it deferred to the discretion used by the ECB and found the OMT mechanism in line with EU law.

The dominance of the Court of Justice as the central judicial body in the $\mathrm{EU}^{46}$ does not bode well with its ability to properly scrutinise measures of economic governance, given that its admissibility threshold is considerably higher in order to manage docket control. ${ }^{47}$ Moreover, once the admissibility threshold is met, the Court usually defers to expertise and maintains a lax review of use of discretion by the ECB, most famously in the OMT case. ${ }^{48}$ In conclusion, neither majoritarian representation nor judicial review as transplanted from the national to the EU level have resulted in legitimation and accountability mechanisms which would have allowed all EU citizens to equally influence policy and decision-making in economic governance, nor their review.

\section{Reconceptualising Accountability Through Self-Governance}

\section{Accountability in the Literature}

Accountability has been the object of legal and political science research alike, which has resulted predominantly in its conceptualisation as a procedural mechanism, relying on the principal-agent model. ${ }^{49}$ Most famously expressed by Bovens, ${ }^{50}$ a procedural concept of accountability leaves out any reference to its content, but rather devises an abstract framework - a procedural checklist once

principle of 'no taxation without representation'. See also PM Huber, 'The Federal Constitutional Court and European Integration' (2015) 21 European Public Law 83, 98.

${ }^{46}$ Asserting its hierarchical superiority in relation to national courts of all levels. See S Rodin, 'Back to the Square One: The Past, the Present and the Future of the Simmenthal mandate' in JM Beneyto and I Pernice (eds), Europe's Constitutional Challenges in the Light of the Recent Case Law of National Constitutional Courts: Lisbon and Beyond (Baden-Baden, Nomos, 2011) 315.

${ }^{47} \mathrm{~S}$ Rodin, 'A Metacritique of the Court of Justice of the EU' Bingham Centre talk, London (2 November 2015), available at: www.biicl.org/documents/772_rodins_paper_2015.pdf?showdocument=1.

${ }^{48}$ Case C-62/14 Gauweiler, above n 14. See also, M Goldoni, 'The Limits of Legal Accountability of the European Central Bank' (2017) 24 George Mason Law Review 595.

${ }^{49}$ GJ Brandsma and J Adriaensen, 'The Principal-Agent Model, Accountability and Democratic Legitimacy' in T Delreux and J Adriaensen (eds), The Principal Agent Model and the European Union (Cham, Switzerland, Springer International, 2017) 37-38, 42.

${ }^{50} \mathrm{M}$ Bovens, 'Analysing and Assessing Accountability: A Conceptual Framework' (2007) 13 European Law Journal 447; M Bovens, D Curtin, and P 't Hart (eds), The Real World of EU Accountability: What Deficit? (Oxford, Oxford University Press, 2010). 
met means the agent has been held accountable in one way or another. While useful in terms of their generalisability, Bovens' and similar procedural frameworks may be misused by decision-makers and reduced to a box-ticking exercise. ${ }^{51}$ They fail to capture conceptually and structurally diverse relationships of any given polity, and consequently cannot be used as a Procrustean bed to accommodate the specificities of EU economic governance. Attempts at substantive conceptualisations of accountability focus predominantly on the nation state as the role model, where the concept of legal accountability introduced by Oliver ${ }^{52}$ has been used as a basis for further research of accountability and legitimacy of the EU more generally. ${ }^{53}$ Alternative models of accountability have been put forward, that can broadly be divided into those mimicking state models of accountability, ${ }^{54}$ or grounding them in Bovens' framework. ${ }^{55}$ As explained above, a notion of accountability inspired by the model of nation states is not appropriate for the study of diverse and uncommon mechanisms employed in the euro crisis. Equally, a mere procedural outlook on accountability may be misused.

In that respect, this chapter adds a novel concept of accountability through self-governance, freed from traditional state-centred mechanisms, and address the idiosyncrasies of EU post-crisis economic governance. While the euro crisis itself has been subject of extensive research, ${ }^{56}$ such accounts only sporadically touch upon the question of accountability, without questioning the design of accountability mechanisms themselves. ${ }^{57}$ I will explain accountability through self-governance in two steps: first, the conceptualisation of accountability in economic governance should be based on the equilibrium between principles of equality and solidarity in order to ensure political equality of EU citizens; and second, such a goal is best achieved through self-governance.

\footnotetext{
${ }^{51}$ For a useful overview of the deficiencies of Bovens' framework, see RL Heidelberg, 'Political Accountability and Spaces of Contestation' (2017) 49 Administration \& Society 1379.

${ }^{52} \mathrm{D}$ Oliver, Government in the United Kingdom. The Search for Accountability, Effectiveness and Citizenship (Milton Keynes, Open University Press, 1991).

${ }^{53}$ See, eg, C Harlow, Accountability in the European Union (Oxford, Oxford University Press, 2002); A Arnull and D Wincott, Accountability and Legitimacy in the European Union (Oxford, Oxford University Press, 2002).

${ }^{54} \mathrm{~J}$ Black, 'Constructing and Contesting Legitimacy and Accountability in Polycentric Regulatory Regimes' (2008) 2 Regulation \& Governance 137, 138.

55 ibid.

${ }^{56}$ See, eg, T Kaarlo and K Tuori, The Eurozone Crisis: A Constitutional Analysis (Cambridge, Cambridge University Press, 2014); T Beukers, B de Witte, and C Kilpatrick (eds), Constitutional Change Through Euro-Crisis Law (Cambridge University Press, 2017); M Dawson, H Enderlein and C Joerges (eds), Beyond the Crisis. The Governance of Europe's Economic, Political, and Legal Transformation (Oxford, Oxford University Press, 2015); A Estella, Legal Foundations of EU Economic Governance (Cambridge, Cambridge University Press, 2018).

${ }^{57}$ In this respect, a line of important questions for re-thinking accountability in post-crisis instruments have been posed in Dawson, "The Legal and Political Accountability Structure of "Post-crisis" EU Economic Governance, above $n 7$.
} 


\section{The Normative Underpinning: The Argument for Self-Governance}

As explained in the examples of the ESM and the OMT, judicial review carried out by the Court of Justice in EU economic governance is problematic as it departs from its focus on the individual, so dominant and pervasive in other areas of EU law. Rather, it gives precedence to the principle of equality of Member States, ${ }^{58}$ through ensuring that principles of conferral and proportionality are satisfied. National courts, furthermore, focused on majoritarian representation to be ensured for budgetary matters. Conversely, the argument put forward here is that any accountability mechanism of EU economic governance should place the individual at the centre. Normatively, I argue, this can be achieved through the application of an equilibrium between the principles of equality and solidarity of Member States, as was the case in previous crises that took place throughout the course of the development of European integration, in order to ensure political equality among all EU citizens - their ability to 'determine politically their destiny. ${ }^{59}$ This argument continues to promote democratic accountability, but in a different manner than that employed in the nation-state context, as it focuses on political equality of citizens as its defining characteristic and requirement. ${ }^{60} \mathrm{Dahl}$ defines the key characteristic of democracy as 'the continuing responsiveness of the government to the preferences of its citizens, considered as political equals. ${ }^{61}$ Political equality of citizens is thus a democratic imperative applicable to the EU more generally, as well as its economic governance.

But what precisely are requirements of the principle of solidarity in the context of EU's economic governance? Durkheim's work on solidarity provides a useful starting theoretical point, as he differentiates between mechanic and organic solidarity. ${ }^{62}$ Mechanic solidarity is present in traditionally small and homogeneous societies, and assumes help is provided on the premise that it will also be received if and when necessary as an act of altruism. Further, organic solidarity exists in modern and heterogeneous societies with a multitude of interests and interdependence, and help is provided based on 'enlightened self-interest' that guides the smooth operation of the system as a whole. ${ }^{63}$

\footnotetext{
${ }^{58}$ For an argument that conditionality reduces the ability of citizens to decide on, for example, redistributive policies on the national level, see M Dawson and F de Witte, 'Self-Determination in the Constitutional Future of the EU' (2015) 21 European Law Journal 371, 373.

${ }^{59}$ Eriksen, above n 19, 13.

${ }^{60}$ See also, G de Búrca, 'Developing Democracy Beyond the State' (2008) 46 Columbia Journal of Transnational Law 101, 130.

${ }^{61}$ RA Dahl, Polyarchy: Participation and Opposition (New Haven, CT, Yale University Press, 1971) 1.

${ }^{62}$ E Durkheim, The Division of Labour in Society (1893; New York, New York Free Press, 1997).

${ }^{63}$ S Fernandes and E Rubio, 'Solidarity Within the Eurozone: How Much, What For, For How Long?' (2012) 51 Notre Europe Policy Paper 3-4.
} 
Applying these categories to the EU legal system, where the precise legal nature of the principle of solidarity is unsettled, ${ }^{64}$ it is possible to see both types of solidarity mechanisms. Mechanic solidarity is evident in the case law on EU citizenship, where the Court of Justice gradually expanded the solidarity obligations of the host Member State, albeit solely after a certain period of integration, or in the words of Domurath, of 'acquired sameness. ${ }^{65}$ Solidarity here is premised on a certain level of integration of free movers into the host Member State. Organic solidarity can be seen in the design of the Cohesion Policy, the aim of which is 'reducing disparities between the various regions and the backwardness of the least-favoured regions. ${ }^{66}$ Solidarity in that sense means recognising the high level of interdependence and a shared sense of advancing European integration to everyone's benefit. ${ }^{67}$

A focus on sovereignty of Member States influenced the division of competences between the EU and the national level in a way that decreased emphasis on solidarity. ${ }^{68}$ This in turn increased the distance between the peoples of Europe, and allowed for the discourse of otherness, labelling some as lazy and debt-creating, and others as hard-working and generating growth. ${ }^{69}$ For German Chancellor Merkel, ' [solidarity] among euro partners should never lead to a debt union, rather it must be about helping others to help themselves' (emphasis added).$^{70}$ Merkel's definition strongly focuses on equality of sovereign Member States, and does not allow for a shared outlook on the crisis and means of its resolution.

Taking a step back into the history of previous crises and ways of their management, the Court of Justice based its reasoning on an interplay between equality of and solidarity between Member States. The early case law of the Court referred to solidarity to justify differentiated measures put in place to remedy the crises of the iron and steel sector in the $1980 \mathrm{~s},{ }^{71}$ and stated that the principle is the basis of the 'entire Community system. ${ }^{72}$ In fact, as Dawson reports, in states that resisted a joint solution to the crisis, out of them most infamously France, did not manage to

${ }^{64}$ A Ott, 'A Flexible Future for the European Union: The Way Forward or a Way Out?' in S Blockmans and S Prechal (eds), Reconciling the Deepening and Widening of the European Union (The Hague, TMC Asser Press, 2007) 153. This is particularly the case in relation to the rights stemming from EU citizenship and the consequences this has for national social welfare systems. C Barnard, 'EU Citizenship and the Principle of Solidarity' in E Spaventa and M Dougan (eds), Social Welfare and EU Law (Oxford, Hart Publishing, 2005) 161-65.

${ }^{65}$ I Domurath, 'The Three Dimensions of Solidarity in the EU Legal Order: Limits of the Judicial and Legal Approach' (2013) 35 Journal of European Integration 459, 463.

${ }^{66}$ See: ec.europa.eu/regional_policy/en/faq/\#1.

${ }^{67}$ In that sense, see M Ross, 'Solidarity - A New Constitutional Paradigm for the EU?' in M Ross and Y Borgmann-Prebil, Promoting Soldiarity in the European Union (Oxford, Oxford University Press, 2010) 30-31.

${ }^{68}$ Domurath, above n 65, 466. See also, M Ekengren et al, 'Solidarity or sovereignty? EU Cooperation in civil protection' (2006) 28 Journal of European Integration 5, 457, 470.

${ }^{69}$ See above, nn 23-25.

${ }^{70}$ Reuters, above n 25.

${ }^{71}$ Case 154/78 Valsabbia v Commission EU:C:1980:81, 59.

${ }^{72}$ Joined Cases 6 and 11/69 Commission v France EU:C:1969:68, 16. 
resolve it on their own. ${ }^{73}$ Presently, the significance of solidarity in crisis management is undoubtedly diminished through an increased emphasis on reciprocity and conditionality. ${ }^{74}$ If used, it is referred to instrumentally, solely for advancing a certain political argument, rather than holding intrinsic value in itself. ${ }^{75}$ It also no longer features in the reasoning of the Court of Justice when reviewing measures of economic governance. Equally, the lack of risk-sharing and its embeddedness in anti-crisis mechanisms further reduced its importance. ${ }^{76}$

Taking the political equality of all EU citizens, ensured through the equilibrium between equality and solidarity as a substantive starting point, I will now move on to explain how it can and why it should be achieved through selfgovernance. The departing premise and an important inspiration in conceiving of the concept of accountability through self-governance in EU economic governance is the 'democracy-striving approach' proposed by Grainne de Búrca, based on 'the principle of fullest possible participation by, and representation of, all those concerned, with a commitment to ensuring the public-regarding nature of the process through continual revision and self-correction. ${ }^{77}$ I therefore argue that, in devising legitimation and accountability mechanisms in economic governance, we need to shift the focus from majoritarian representation to the political equality of citizens as more suitable for the EU as a transnational context. ${ }^{78}$ Teubner heavily criticises the perseverance on identitarian consensus building (put into effect through majoritarian representation) as the necessary condition of democracy, which he considers unattainable in transnational contexts. ${ }^{79}$ Rather, he focuses on the achievement that 'confrontation with alternative world views is at the centre of democratic communication. ${ }^{80}$ In the context of transnational regimes, he finds that representation should be surpassed and substituted by self-contestation - a responsiveness of a given transnational polity or regime to external frustrations as well as the institutionalisation of internal dissent. ${ }^{81} \mathrm{He}$ also rightly adds that any such institutional imagination can only be context-specific. ${ }^{82}$

\footnotetext{
${ }^{73}$ M Dawson, New Governance and the Transformation of European Law. Coordinating EU Social Law and Policy (Cambridge, Cambridge University Press, 2011) 37.

${ }^{74}$ McDonnell, above n 13, 78 .

${ }^{75}$ A Grimmel, 'Solidarity in the EU: Fundamental Value or "Empty Signifier" in A Grimmel and S My Giang (eds), Solidarity in the European Union. A Fundamental Value in Crisis (Cham, Switzerland, Springer International, 2017) 163-64.

${ }^{76}$ MP Maduro, 'A New Governance for the European Union and the Euro: Democracy and Justice' (2013) 16 Yearbook of Polish European Studies 111, 115.

${ }^{77}$ de Búrca, above n 60, 157. See also, K Nicolaïdis, 'Democratic Theory and Europe's Institutional Architecture in Times of Crisis' in S Piattoni (ed), The European Union: Democratic Principles and Institutional Architectures in Times of Crisis (Oxford, Oxford University Press, 2015) 153.

${ }^{78}$ See also, Dawson, New Governance and the Transformation of European Law, above n 73, 13.

${ }^{79}$ Teubner, above n 10,6 .

${ }^{80}$ ibid 7.

81 ibid.

${ }^{82}$ ibid, 8 . I concur with this position in relation to the design of accountability mechanisms in EU economic governance, below.
} 
In line with de Búrca and Teubner, I propose a framework of legal accountability in EU economic governance through self-governance. In conceptualising accountability through self-governance, I concur with Pernice that the EU should be conceived also as a community of citizens, rather than one exclusively of states. ${ }^{83}$ From the aspect of accountability, Dawson argues it does not need to be imagined in vertical terms towards a hierarchically superior sovereign, but can be imagined in horizontal terms. ${ }^{84}$ On this basis, self-governance, as conceived and developed by Vincent Ostrom, ${ }^{85}$ becomes the normative driver of conceiving accountability detached from majoritarian representation as the only defining quality of democracy beyond the state. Self-governance places the informed, active, aware and involved citizen, who is a member of a range of social groups, at the centre of governance mechanisms of a community ${ }^{86}$ As explained by Ostrom:

The future belongs to those whose covenants are bonds of mutual trust grounded in principles of self-governance and who learn to use processes of conflict and conflict resolution to elucidate information, clarify alternative, stimulate innovation, and extend the frontiers of inquiry to open new potentials for human development. ${ }^{87}$

Teubner equally finds that a high learning capacity is a necessary condition for any imagination of democracy in transnational contexts which would then allow for organised dissent (contestation) ${ }^{88}$ In addition, according to Domurath, learning is crucial for the enhancement of transnational solidarity. ${ }^{89}$ Understood in this way, self-governance is capable of promoting the equilibrium between the principles of solidarity and equality in economic governance. A self-governed, enlightened and educated European citizen will acquire a sense of community of a transnational scope, and feel more attachment to other European citizens and their specific circumstances. ${ }^{90}$ The sense of community among citizens beyond

\footnotetext{
${ }^{83}$ Pernice, above n 29, 543.

${ }^{84}$ Dawson, New Governance and the Transformation of European Law, above n 73, 95.

${ }^{85}$ See V Ostrom, The Meaning of American Federalism: Constituting a Self-Governing Society (San Francisco, ICS Press, 1994); V Ostrom, The Political Theory of a Compound Republic: Designing the American Experiment (Lanham, MD, Lexington Books, 2007); V Ostrom, The Intellectual Crisis in Public Administration (Alabama, University of Alabama Press, 1973); P Aligica and V Tarko, 'Polycentricity: From Polanyi to Ostrom, and Beyond' (2012) 25 Governance: An International Journal of Policy, Administration, and Institutions 237, 246.

${ }^{86}$ Ostrom, The Meaning of American Federalism, above n 85. A similar concept can be found in the idea of individual self-determination. Dawson and de Witte rightly argue that such an advanced manner of political participation is not yet achieved at the EU level. See M Dawson and F de Witte, 'Constitutional Balance in the EU after the Euro-Crisis' (2013) 76 Modern Law Review 817, 819-20. Floris de Witte does find some manifestation of individual self-determination through the use of free movement rules, where citizens move beyond the spaces for political self-determination of a nation state. See F De Witte, 'Transnational Solidarity and the Mediation of Conflicts of Justice in Europe' (2012) 18 European Law Journal 698. The proposal of self-governance takes this idea further and argues for the creation of spaces of political self-determination, to use the vocabulary of Dawson and de Witte, at the level of EU economic governance.

${ }^{87}$ Ostrom, The Meaning of American Federalism, above n 85, 272.

${ }^{88}$ Teubner, above n 10,7 .

${ }^{89}$ Domurath, above n 65, 471.

${ }^{90}$ P Hilpold, 'Understanding Solidarity within EU Law: An Analysis of the "Islands of Solidarity" with Particular Regard to Monetary Union’ (2015) 34 Yearbook of European Law 257, 264.
} 
the confines of the nation state promotes their equality, but also mutual support when needed. ${ }^{91}$

In consequence, I argue that if agentive European citizens viewed themselves, as oppose to Member States, as central to the integration project, they will be able to more effectively contest and demand answers from those making decisions that affect them. ${ }^{92}$ In line with de Búrca's 'democracy-striving approach', such processes must be subject to permanent re-evaluation and self-correction..$^{93}$ In addition, moving the focus away from the Member States and to the citizens, my normative argument is that self-governance will inherently strive to achieve an equilibrium between solidarity and equality in economic governance of the EU.

\section{Conclusion: Applying the Model to Current Mechanisms of Economic Governance}

From an empirical point of view, prevalence of either the principle of equality or solidarity would have negative consequences for economic governance. Insistence on formal equality, as was shown earlier, contributes to prolonging actual inequalities between Member States, but more importantly, between its citizens. Dominance of the principle of solidarity could lead to free-riding of debtor states in the short term, and may encourage fiscal irresponsibility. For this reason, as I have argued above, self-governance offers a route that reconciles the two principles and achieves political equality of all EU citizens. In this final section, I will offer some initial thoughts on possibilities for institutional design of economic governance mechanisms that would allow for genuine political and legal accountability through self-governance.

The starting point of this exercise is found in Article 10(3) TEU: 'Every citizen shall have the right to participate in the democratic life of the Union. Decisions shall be taken as openly and as closely as possible to the citizen'. Yet, in the area of economic governance, economic policy is reserved for Member States, ${ }^{94}$ whereas the size of the EU's population has stood in the way of a more concrete application of Article 10(3) TEU to monetary policy. ${ }^{95}$ However, large-scale bottom-up

\footnotetext{
${ }^{91}$ Domurath, above n 65, 460.

${ }^{92}$ For entertaining a similar approach, see Dawson, New Governance and the Transformation of European Law above n 73, 94. A broader idea of political self-governance would also include the ability of citizens to influence decision- and policy-making bottom-up. For a comprehensive contribution of the theory of polycentricity premised on self-governance as a political theory for the European Union, see J van Zeben and A Bobić (eds), Polycentricity in the European Union (Cambridge, Cambridge University Press, 2019).

${ }^{93}$ See above $n 77$.

${ }^{94}$ Art 5(1) TFEU.

${ }^{95}$ It is important to note that according to Art 5(3) TEU, the principle of subsidiarity does not apply to monetary policy for those Member States whose currency is the euro, given that it is an exclusive competence of the EU according to Art 3(1)(c) TFEU.
} 
economic decision-making is not without precedent, as the case of participatory budgeting aptly shows. In essence, participatory budgeting allows non-elected citizens to make decisions on the allocation of public finances. ${ }^{96}$ It entails a discussion and public deliberation on limited resources, with the involvement of the elected body of the administrative unit in question (city, region, etc), on a repeated basis, with an accountability mechanism in place. ${ }^{97}$ Applied first in Porto Alegre, a city of 1.3 million inhabitants, ${ }^{98}$ and having spread across Brazil and Latin America from 1989 onwards, ${ }^{99}$ participatory budgeting provided a way for empowerment of large urban communities in learning about budgeting, and participating in its creation. ${ }^{100}$ The initial experiments have developed into fully functioning frameworks of participatory budgeting that account for 2 to 10 per cent of the overall implemented budgets, where 9 per cent is the average. ${ }^{101}$

Participatory budgeting has been implemented in an increasing number of European cities as well, ${ }^{102}$ drawing upon the model of Porto Alegre or similar variations. The benefits of the system are well documented - ranging from increased participation of minorities and their interests, ${ }^{103}$ a significant increase in transparency and communication between the citizens and the elected bodies, and the ensuing comprehensive modernisation of the system. ${ }^{104}$ Another reported benefit is the participation of citizens in the creation of the framework of participatory budgeting itself, with a strong presence of a social justice agenda in devising this framework. ${ }^{105}$

The benefits of a participatory budgeting model directly correspond to the flaws described above in the system of EU's economic governance. Most importantly, these concern the political equality of citizens in participation, as well as an increase in transparency and communication with the institutions. As far as the euro crisis is concerned, participatory budgeting lends itself as a way for EU citizens to decide on broad-brush monetary policy decisions, as well as the extent of solidarity to be applied in the creation of post-crisis mechanisms and the ultimate allocation of resources. For example, participatory budgeting as a model could be applied to the institutional design of the successor to the ESM, reforms addressing long-term budgetary discipline, as well as to the allocation of competences

\footnotetext{
${ }^{96}$ Y Sintomer, C Herzberg and A Röcke, 'Participatory Budgeting in Europe: Potentials and Challenges' (2008) 32 International Journal of Urban and Regional Research 164, 168.

${ }^{98}$ Other large cities that use participatory budgeting in Brazil are Recife (1.4 million), Belém (1.3 million), Belo Horizonte (2.3 million), as well as Montevideo, Uruguay (1.4 million). Y Cabannes, 'Participatory Budgeting: A Significant Contribution to Participatory Democracy' (2004) 16(1) Environment \& Urbanization 27, 30.

${ }^{99}$ ibid, 30.

${ }^{100}$ For a broader analysis, see G Baiocchi and E Ganuza, 'Participatory Budgeting as if Emancipation Mattered' (2014) 42 Politics \& Society 29.

${ }^{101}$ Cabannes, above n 98, 34 .

${ }^{102}$ Sintomer, Herzberg and Röcke, above n 96, 169.

${ }^{103}$ Cabannes, above n 98, 39.

${ }^{104}$ Sintomer, Herzberg and Röcke, above n 96, 174.

105 ibid, 167.
} 
to the ECB. EU citizens can also decide under which circumstances individual Member States can receive financial aid without furthering the gap between debtor and creditor states. The experience of participatory budgeting across the EU could in this sense serve as an experimental basis for a more serious engagement with bottom-up mechanisms of participatory democracy. This would mean that political accountability of decision-makers does not depend on the success of its output, but is rather strongly legitimated by the input of self-governed citizens. Furthermore, Member States would no longer be able to bypass the individual by way of their focus on equality of sovereign Member States.

Furthermore, promoting and securing self-governance in the judicial review stage appears counterintuitive: if self-governance is secured in the political arena, the role of the courts should be negligible, given the importance of bottom-up political influence of citizens. However, Scott and Sturm see a new role for courts in forms of new governance as catalysts. ${ }^{106}$ They give examples from the jurisprudence of the Court of Justice on how courts can contribute to new forms of governance, which aligns with Ostrom's ideals of structures of conflict resolution to 'elucidate information, clarify alternative, stimulate innovation, and extend the frontiers of inquiry to open new potentials for human development. ${ }^{\prime}{ }^{107}$ These include a rethink of standing rules to more closely reflect the design of EU acts under review, such as the expansion of standing to those who had the right to be consulted in the decision-making process itself. Furthermore, Scott and Sturm add that courts' interpretations can have an additional epistemic role by way of focusing on the quality of the information-gathering and the peer-review process used to justify EU action and policies. Finally, they underline the reflexive role that jurisprudence can have on future design of policy- and decision-making by emphasising the importance of the inclusive, deliberative and participatory nature of new forms of governance, ${ }^{108}$ also including polycentric self-governance.

Judicial review on both the EU and national level should therefore take both principles into account. For example, had the Court of Justice in its Pringle decision on the ESM placed an emphasis on the principle of solidarity as its rationale, it may have found the ESM Treaty incompatible with the EU legal system. This could have meant that less emphasis be placed on conditionality, and providing more leverage for debtor states in the negotiations of bail-out conditions. ${ }^{109}$ On the national level, considerations of solidarity, in particular taking into account that

\footnotetext{
${ }^{106} \mathrm{~J}$ Scott and S Sturm, 'Courts as Catalysts: Re-thinking the Judicial Role in New Governance' (2006) 13 Columbia Journal of European Law 565.

${ }^{107}$ Ostrom, The Meaning of American Federalism, above n 85, 272.

${ }^{108}$ Scott and Sturm, above n 106, 573-74.

${ }^{109}$ According to the long-standing jurisprudence of the Court of Justice, treaties concluded by EU institutions and Member States must be compatible with EU law and cannot put into question the specific features of EU law and its autonomy. See, eg, Case 22/70 Commission v Council EU:C:1971:32, 17; Opinion 3/94 EU:C:1995:436, 17; Opinion 1/91 EU:C:1991:490, 25-29, 46; Opinion 1/09 EU:C:2011:123, 48; Opinion 2/13 EU:C:2014:2454, 146.
} 
the euro crisis is one of a joint origin, ${ }^{110}$ could perhaps have led to less emphasis on conditionality being placed by the Bundesverfassungsgericht in reviewing the OMT, in particular after the positive effects of the OMT's announcement to the euro area as a whole.

Ultimately, self-governance as a concept is under-researched and difficult to apply to a large-scale organisation such as the EU. However, it was the argument of this contribution that the current deficiencies in the accountability structure of the EU's economic governance can be remedied through self-governance, essentially a bottom-up influence of citizens on the creation and design of economic governance mechanisms. The institutions further applying these mechanisms gain an increase in legitimacy and accountability to those citizens, without separating them across Member States.

\footnotetext{
${ }^{110}$ Fernandes and Rubio explain the causes of the euro crisis as going well beyond Greece's falsification of statistical budgetary data on meeting the Maastricht criteria for entering the eurozone. Their claim is that the crisis could have been prevented, or better managed, had it not been for the failure of politicians to see interdependence and spillovers in the common currency area; also, policy-making lacked a more serious policing of national budgets in the EMU: Fernandes and Rubio, above n 63, 19-20.
} 
